\title{
Analisa Denyut Jantung Menggunakan Aplikasi Mobile Self Integrated BioInformatics System
}

\author{
Rani Purbaningtyas \\ Program Studi Teknik Informatika \\ Universitas Bhayangkara Surabaya \\ Surabaya, Indonesia \\ raniubhara@gmail.com
}

\begin{abstract}
Heart disease is still ranked first in the WHO most dangerous and deadly disease in the world. The individual's reluctance to check his heart condition routinely also influence this condition. So we need an application that can help overcome this. SIBioS application is a mobile-based application that functions to analyze heart rate. SIBioS is useful to help with the initial diagnosis of the presence or absence of cardiovascular disorders in individuals. The method applied for data analysis in SIBioS applications is case-based reasoning. Each heart rate data obtained calculated the degree of closeness of the distance to the heart rate contained in the knowledge base owned. If the Resting Heart Rate (RHR) value is in the range of $60-100$ (under certain conditions), then it is said to be healthy. The user indicates bradycardia cardiovascular disorders if RHR value less than 60 . Conversely, if over 100 indicated tachycardia cardiovascular disorders. Analysis of the Target Heart Rate (THR) value obtained is a reference for physical activity recommendations for users. The test results show that SIBioS can provide information about the status of the heart condition tester following the real condition of the tester at the time of measurement. Besides, other factors also influenced the results of heart rate data analysis. There are tapping data devices, gender, age, daily physical activity, profession, status, and other supporting factors. The physical activity recommendations given by the system are determined based on the individual's heart condition.
\end{abstract}

Keywords-heart rate analysis, mobile application, casebased reasoning.

\footnotetext{
Abstrak - Penyakit jantung masih menduduki peringkat pertama penyakit paling berbahaya dan mematikan di dunia versi WHO. Hal ini juga dipengaruhi faktor keengganan individu untuk memeriksakan kondisi jantungnya secara rutin. Sehingga dibutuhkan aplikasi yang mampu membantu mengatasi hal tersebut. Aplikasi SIBioS merupakan aplikasi berbasis mobile yang berfungsi untuk menganalisa denyut jantung. SIBioS berguna untuk membantu diagnosis awal ada atau tidaknya gangguan kardiovaskuler pada individu. Metode yang diterapkan untuk analisa data pada aplikasi SIBioS adalah case based reasoning. Setiap data denyut jantung yang didapat akan dihitung tingkat kedekatan jaraknya terhadap denyut jantung yang terdapat dalam basis pengetahuan yang dimiliki. Jika nilai Resting Heart Rate (RHR) berada di kisaran 60-100 (dalam kondisi tertentu) maka dikatakan normal. Jika kurang dari 60 dicurigai ada indikasi gangguan kardiovaskuler bradycardia. Sebaliknya jika diatas 100 terindikasi gangguan kardiovaskuler tachycardia. Analisa terhadap nilai Target Heart Rate (THR) yang didapat menjadi acuan rekomendasi aktivitas fisik bagi pengguna. Hasil pengujian menunjukkan, SIBioS mampu memberikan
}

informasi tentang status kondisi jantung tester sesuai dengan kondisi riil tester pada saat dilakukan pengukuran. Hasil analisa data denyut jantung juga dipengaruhi oleh faktor piranti smartwatch yang digunakan sebagai media tapping data denyut jantung, jenis kelamin, usia, aktivitas fisik harian, status profesi individu dan faktor pendukung pada saat dilakukan pengukuran resting heart rate. Rekomendasi aktifitas fisik yang diberikan oleh sistem ditentukan berdasarkan kondisi jantung individu tersebut.

Keywords-analisa denyut jantung, aplikasi mobile, casebased reasoning

\section{PENDAHULUAN}

Menurut daftar yang dirilis oleh WHO di tahun 2017, penyakit jantung masih menduduki peringkat ke-1 penyakit paling berbahaya dan mematikan di dunia [1] dan menduduki peringkat kedua penyakit paling berbahaya dan mematikan di Indonesia. Oleh sebab itu, banyak penelitian yang dilakukan yang mengambil topik penelitian tetang jantung. Salah satunya adalah pembuatan aplikasi Self Integrated BioInformatics System (SIBioS). Aplikasi SIBioS merupakan aplikasi berbasis mobile yang berfungsi untuk menganalisa denyut jantung. Melalui aplikasi ini dapat memudahkan masyarakat untuk mengetahui apakah denyut jantungnya normal atau tidak. Hal ini berguna sebagai diagnosis awal ada atau tidaknya gangguan kardiovaskuler pada orang tersebut [2]. Pada hasil penelitian SIBioS sebelumnya ditunjukkan bagaimana proses tapping data denyut jantung pengguna dan konversi hasil bacaan data denyut jantung pengguna dalam format grafik. Selain itu juga ditampilkan kondisi pendukung yang berpengaruh terhadap denyut jantung pengguna. Sedangkan pada penelitian ini menjelaskan bagaimana proses analisa data denyut jantung pengguna tersebut.

Proses kerja yang terjadi di SIBioS adalah setelah dilakukan tapping data denyut jantung, maka data tersebut akan dianalisa lebih lanjut. Dalam hal ini, metode yang digunakan pada saat analisa data memegang peranan penting untuk menentukan hasil analisa terhadap denyut jantung orang tersebut. Salah satu metode yang bisa digunakan adalah case-based reasoning.

Case-based reasoning merupakan salah satu metode penalaran yang digunakan dalam sistem pakar. Pada cased- based reasoning, suatu basis pengetahuan tentang kasus berisi kasus-kasus dengan solusi yang telah dicapai. Untuk menemukan solusi dari kasus yang baru, maka sistem akan mencari kasus yang baru tersebut dalam basis pengetahuan kasus yang dimiliki, yang memiliki tingkat kesamaan yang paling tinggi dengan kasus yang dicari 
tersebut. Salah satu metode yang digunakan untuk menghitung tingkat kesamaan kasus adalah Euclidian distance.

Berdasarkan penjelasan diatas, maka metode penalaran case-based reasoning dipilih untuk diterapkan pada aplikasi SIBioS. Nantinya setiap data denyut jantung yang didapat akan dihitung tingkat kedekatan jaraknya terhadap denyut jantung yang terdapat dalam basis pengetahuan yang dimiliki. Sehingga dapat diinformasikan status denyut jantung orang tersebut.

\section{TINJAUAN PUSTAKA}

Self Integrated BioInformatics System (SIBioS) merupakan sistem informasi berbasis mobile yang mengimplementasikan konsep bioinformatika khususnya organ jantung. Aplikasi SIBioS berupa aplikasi yang berjalan pada perangkat mobile sistem operasi Android dengan 2 fitur utama yaitu :

1. informasi tentang normal tidaknya denyut jantung seseorang

2. rekomendasi aktivitas untuk mendukung pemeliharaan jantung yang didasarkan pada kondisi jantung orang tersebut.

Cara kerja SIBioS adalah sebagai berikut :

1. SIBioS menerima data masukan utama melalui perangkat bantu jenis smartwatch.

2. Piranti smartwatch yang telah terhubung dengan smartphone melalui koneksi bluetooth akan mengirimkan data hasil bacaan heart rate pengguna smartwatch tersebut ke aplikasi SIBioS

3. Data ini akan diteruskan ke dalam sistem dan dikombinasikan dengan data pendukung yang merupakan faktor-faktor yang berpengaruh pada normal tidaknya denyut jantung seseorang pada saat pengukuran denyut jantung meliputi usia dan tingkat aktivitas fisik.

4. Dengan menerapkan case based reasoning, data denyut jantung ini nantinya akan dianalisa lebih lanjut untuk menentukan apakah denyut jantung individu tersebut termasuk dalam kategori normal atau mengarah kepada adanya gangguan kardiovaskuler.

5. SiBIOS juga memberikan keluaran berupa rekomendasi aktivitas untuk mendukung pemeliharaan jantung yang didasarkan pada kondisi jantung orang tersebut.

Dalam penentuan status kondisi jantung individu dan pemberian rekomendasi aktivitas terhadap individu, SIBioS menerapkan metode case-based reasoning. Case based reasoning merupakan metode penyelesaian suatu kasus dengan menggunakan/mengadopsi dari penyelesaian kasus-kasus lama yang pernah ditangani sebelumnya untuk menjelaskan/memberikan solusi penyelesaian terhadap kasus-kasus yang baru [3,4]. Terdapat 4 proses yang terjadi pada case-based reasoning dalam penyelesaian masalah [5] seperti terlihat pada gambar 1 :

1. Retrieve (Memperoleh Kembali) : pada proses ini sistem akan melakukan identifikasi parameter pencocokan yang dapat dijadikan sebagai acuan lalu melakukan pencarian kasus lama yang memiliki kesamaan dengan kasus baru.

2. Reuse (Menggunakan) : pada proses ini sistem akan menggunakan kembali informasi yang berasal dari kasus sebelumnya atau sistem akan melakukan adaptasi terlebih dahulu untuk memecahkan masalah pada kasus yang baru.
3. Revise (Meninjau) : pada proses ini sistem akan meninjau kembali solusi yang telah didapatkan dari kasus yang lama.

4. Retain (Menyimpan) : pada proses ini apabila ternyata ditemukan solusi baru yang lebih baik dari solusi yang telah ada sebelumnya maka solusi baru tersebut akan diberi indeks dan disimpan untuk kemudian digunakan kembali pada kasus serupa pada masa yang akan datang.

Sesuai dengan tahap-tahap tersebut, Aamodt dan Piaza, menggambarkan case-based reasoning dalam sebuah sebuah siklus yang disingkat $4 \mathrm{R}$ yaitu, Retrieve, Reuse, Revise dan Retain seperti pada gambar berikut ini [6] :

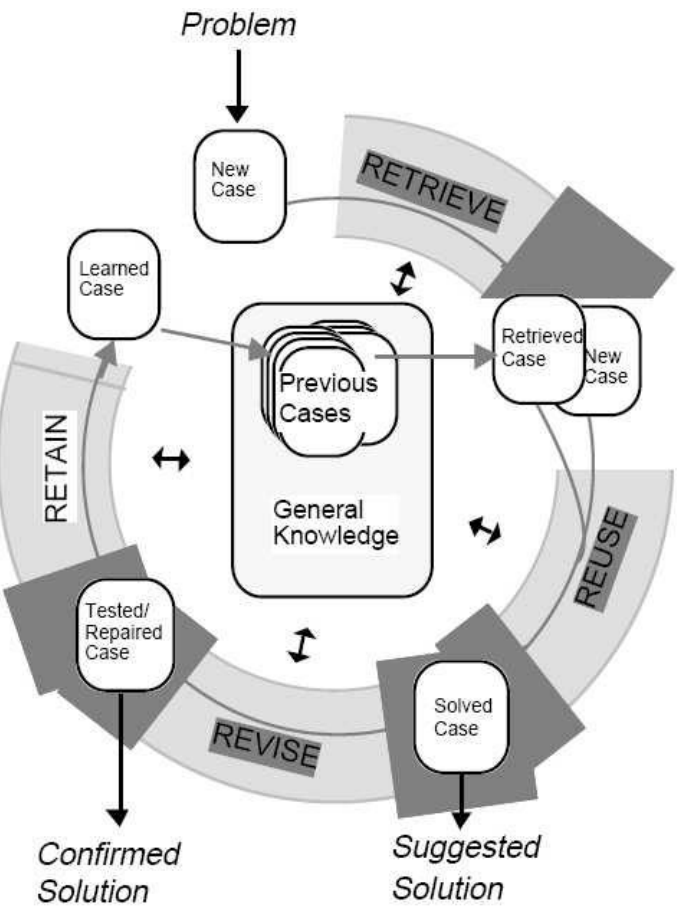

Gambar 1. Siklus case-based reasoning

Salah satu tahap penting dalam siklus case-based reasoning adalah pengambilan kembali (retrieval) terhadap kasuskasus sebelumnya sehingga dapat digunakan kembali untuk menyelesaikan permasalahan yang baru. Salah satu yang dijadikan pertimbangan dalam banyak penelitian adalah penilaian kesamaan (similarity assesment). Ada beberapa metode yang digunakan untuk menghitung tingat kesamaan [7,8] salah satunya adalah metode Euclidean distance [9].

Jarak merupakan pendekatan yang umum dipakai untuk mewujudkan pencarian kasus. Fungsinya adalah untuk menentukan kesamaan atau ketidaksamaan dua kasus. Tingkat kesamaan dinyatakan dengan suatu skor atau ranking. Semakin kecil nilai ranking maka akan semakin dekat tingkat kesamaan kedua kasus tersebut [10]. Persamaan dari Euclidean distance dapat dituliskan sebagai berikut [11]:

$$
d(P, Q)=\sqrt{\sum_{j=1}^{p}\left(x_{j}(P)-x_{j}(Q)\right)^{2}}
$$




\section{METODE PENELITIAN}

Seperti dijelaskan sebelumnya, proses analisa data pada aplikasi SIBioS menerapkan metode case-based reasoning dan Euclidean distance. Jika digambarkan dalam bentuk flowchart, proses analisa data pada aplikasi SIBioS adalah sebagai berikut :

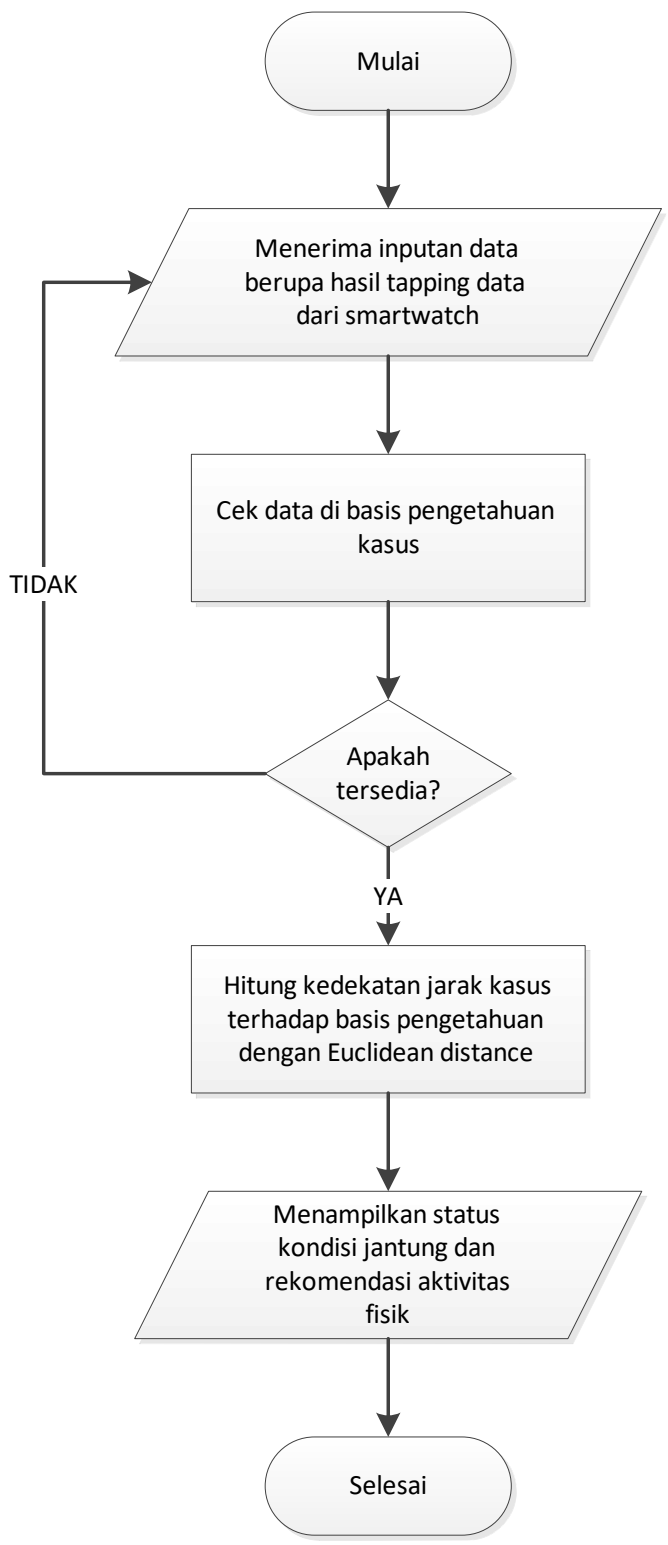

Gambar 2. Alur analisa denyut jantung dengan menerapkan case-based reasoning dan Euclidean distance

Beberapa istilah dan ketentuan formulasi perhitungan yang digunakan pada saat analisa data kondisi jantung adalah sebagai berikut :

1. Heart Rate (HR) adalah jumlah detak jantung per satuan waktu, biasanya dinyatakan dalam denyut per menit atau beats per minute (bpm). Detak jantung bervariasi tergantung pada kebutuhan tubuh untuk menyerap Oksigen dan mengeluarkan $\mathrm{CO} 2$ dalam berbagai keadaan, misalnya saat olah raga atau tidur.

2. Resting Heart Rate (RHR) adalah jumlah detak jantung seseorang pada saat istirahat. Saat paling tepat untuk mengukur heart rate istirahat ini adalah saat bangun tidur di pagi hari, sesudah tidur malam yang nyenyak. Angka kisaran heart rate istirahat antara 60 - 80 detak tiap menit. Resting heart rate biasanya semakin besar sejalan dengan pertambahan usia, dan biasanya seseorang yang banyak berolah raga memiliki detak jantung istirahat yang lebih rendah. Resting heart rate ini merupakan salah satu parameter untuk menentukan training target heart rate. Nilai RHR pada penelitian ini didapat dari hasil tapping data pada smartwatch yang dipakai individu.

3. Maximum Heart Rate (MHR) adalah jumlah detak jantung tertinggi per menit yang dapat memompa di bawah tekanan maksimum. Nilai MHR tiap individu akan berbeda-beda karena dipengaruhi oleh faktor usia. Perhitungan nilai MHR dapat dilihat pada persamaan berikut ini :

$$
\mathrm{MHR}=220-\text { usia }
$$

4. Reserve Heart Rate (HRR) adalah selisih antara resting heart rate dan maximum heart rate. Perhitungan nilai HRR dapat dilihat pada persamaan berikut ini :

$$
\mathrm{HRR}=\mathrm{MHR}-\mathrm{RHR}
$$

5. Target Heart Rate (THR) adalah rentang detak jantung yang diinginkan dicapai selama latihan aerobik yang memungkinkan jantung dan paru-paru seseorang untuk menerima manfaat paling banyak dari latihan. Kisaran teoritis ini bervariasi berdasarkan kondisi fisik seseorang, jenis kelamin, dan pelatihan sebelumnya. Nilai THR dipengaruhi oleh level aktivitas individu.

6. Beberapa faktor yang mempengaruhi analisa denyut jantung pada aplikasi SIBioS adalah piranti smartwatch yang digunakan untuk tapping data, jenis kelamin, usia, aktivitas fisik harian, status profesi individu dan faktor pendukung pada saat dilakukan pengukuran RHR.

7. Denyut jantung dikatakan normal jika nilai RHR berada di kisaran 60 hingga 100 dengan syarat dan kondisi tertentu. Jika nilai RHR berada kurang dari 60 maka ada kecenderungan akan gangguan kardiovaskuler bradycardia. Sebaliknya, jika nilai RHR berada diatas 100 maka ada kecenderungan akan gangguan kardiovaskuler tachycardia.

8. THR berada di kisaran 50\%-70\% terhadap nilai HRR dan RHR jika level aktifitas fisik individu termasuk dalam kategori sedang/moderate. Sebaliknya THR berada di kisaran 70\%-85\% terhadap nilai HRR dan RHR jika level aktifitas fisik individu termasuk dalam kategori berat.

\section{HASIL DAN PEMBAHASAN}

Aplikasi SIBioS diujicobakan terhadap 3 kasus yang berbeda sebagai berikut :

1. Data profil tester pertama adalah sebagai berikut : Ponirah, seorang wanita berusia 65 tahun dengan berat badan $58 \mathrm{~kg}$ memiliki level tingkat aktivitas sedang 


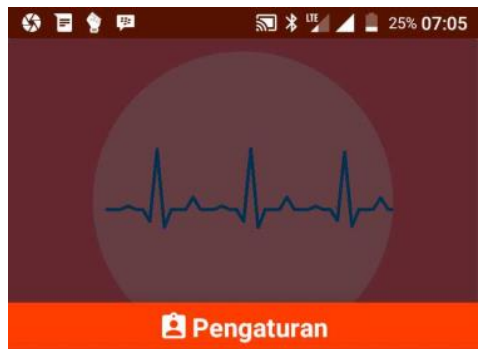

PROFILE

Nama ponirah

Usia 65

Berat Badan $\quad 58$

Akrifitas

Sedang

SIMPAN

Gambar 3. Data profil dari tester pertama

Hasil pengukuran denyut jantung tester Ponirah dengan menggunakan aplikasi SIBioS menunjukkan informasi sebagai berikut :
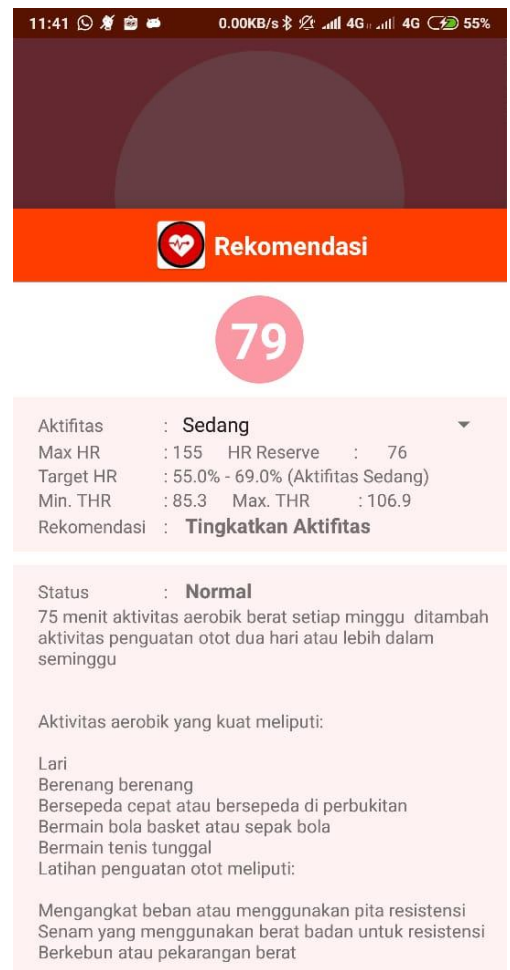

Gambar 4. Hasil pengukuran dan analisa denyut jantung tester pertama pada level aktivitas "Sedang"

Berdasarkan profil tester diatas, karena hasil pengukuran denyut jantung tester pada saat pengujian adalah 79. Maka nilai RHR adalah 79. Nilai RHR individu pada saat pengujian termasuk dalam kategori "Normal".

Selanjutnya dilakukan perhitungan nilai MHR dan HRR seperti pada persamaan 2 dan persamaan 3 agar dapat ditentukan nilai THR. Nilai MHR dan HRR individu yang didapat pada saat pengujian masing-masing bernilai 155 dan 76.

Perhitungan nilai THR selain ditentukan oleh nilai MHR dan HRR juga dipengaruhi oleh level aktivitas tester. Pada saat pengujian berlangsung, ditentukan status aktivitas tester yaitu "Sedang". Rekomendasi aktivitas ditambahkan informasi tentang standar nilai minimum dan maksimum target denyut jantung yang harus dicapai. Target denyut jantung yang harus dicapai berada di kisaran 85,3 hingga 106,9. Target denyut jantung ini didapat dari hasil perhitungan sebagai berikut :

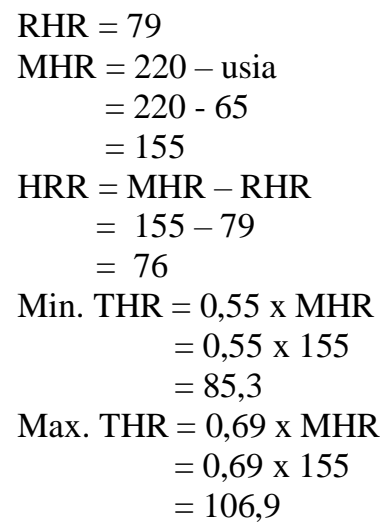

Rekomendasi aktivitas yang diberikan oleh sistem untuk mencapai target denyut jantung yang dituju adalah "Tingkatkan aktivitas" dengan diberikan beberapa alternatif pilihan aktivitas yang dapat dilakukan oleh tester. Hal ini dikarenakan hasil tapping data RHR masih dibawah nilai minimal THR yang harus dicapai.

Profil tester diatas dilakukan uji coba dengan cara merubah status level tingkat aktivitas tester dari yang awalnya "Sedang" menjadi "Berat" didapatkan hasil sebagai berikut :
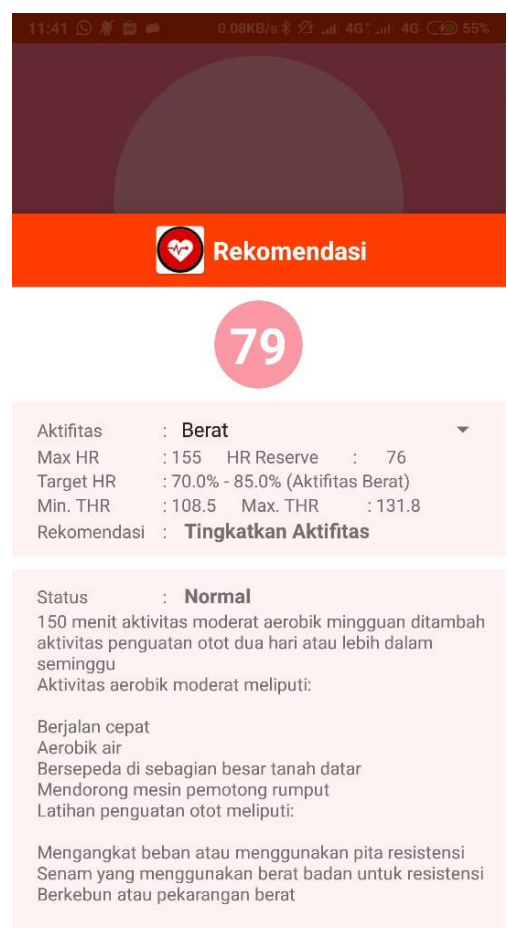

Gambar 5. Hasil pengukuran dan analisa denyut jantung tester pertama pada level aktivitas "Berat" 
Berdasarkan data profil tester diatas, karena hasil pengukuran denyut jantung tester pada saat pengujian adalah 79 maka status kondisi jantung termasuk dalam kategori "Normal". Rekomendasi aktivitas disesuaikan dengan status aktivitas tester yaitu "Sedang" dengan diberikan informasi tentang standar nilai minimum dan maksimum target denyut jantung yang harus dicapai. Target denyut jantung yang harus dicapai berada di kisaran 108,5 hingga 131,8 . Target denyut jantung ini didapat dari hasil perhitungan sebagai berikut :

$$
\begin{aligned}
& \mathrm{RHR}=79 \\
& \text { MHR }=220-\text { usia } \\
& =220-65 \\
& =155 \\
& \mathrm{HRR}=\mathrm{MHR}-\mathrm{RHR} \\
& =155-79 \\
& =76 \\
& =0,7 \times 155 \\
& =108,5 \\
& =0,85 \times 155 \\
& =131,8
\end{aligned}
$$

Rekomendasi aktivitas yang diberikan oleh sistem untuk mencapai target denyut jantung yang dituju adalah tetap "Tingkatkan aktivitas" dengan diberikan beberapa alternatif pilihan aktivitas yang dapat dilakukan oleh tester. Sebab meski level aktivitas tester sudah diubah menjadi "Berat", hasil tapping data RHR masih dibawah nilai minimal THR yang harus dicapai. Sehingga rekomendasi aktivitas adalah tetap "Tingkatkan aktivitas"

2. Data profil tester kedua adalah sebagai berikut :

Arif Arizal, seorang pria berusia 31 tahun dengan berat badan $70 \mathrm{~kg}$ yang memiliki level tingkat aktivitas sedang.

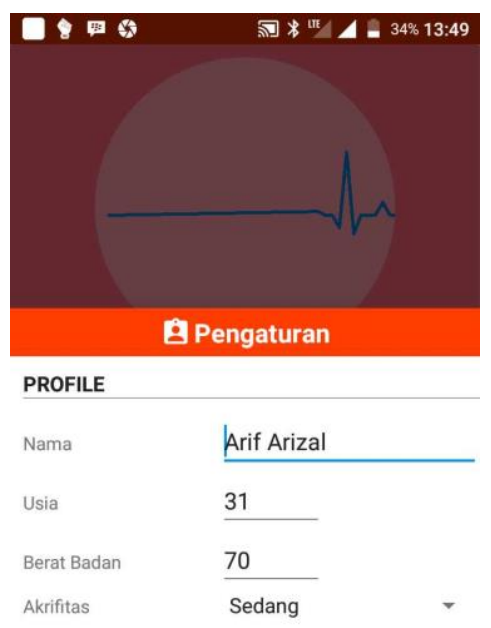

$$
\text { SIMPAN }
$$

Gambar 6. Data profil tester kedua
Hasil pengukuran denyut jantung dari tester Arif Arizal menunjukkan informasi sebagai berikut :
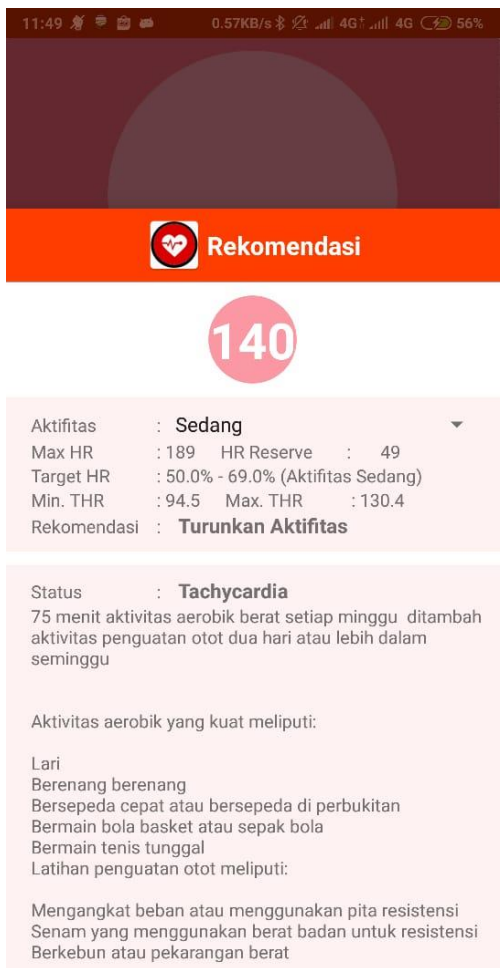

Gambar 7. Hasil pengukuran dan analisa denyut jantung tester kedua pada level aktivitas "Sedang"

Berdasarkan profil tester diatas, karena hasil pengukuran denyut jantung tester adalah 140 maka status kondisi jantung ada kecenderungan untuk mengalami "Tachycardia". Rekomendasi aktivitas disesuaikan dengan status aktivitas tester yaitu "Sedang" dengan diberikan informasi tentang standar nilai minimum dan maksimum target denyut jantung yang harus dicapai agar kondisi jantung menjadi "Normal". Target denyut jantung yang harus dicapai berada di kisaran 94,5 hingga 130,4. Target denyut jantung ini didapat dari hasil perhitungan sebagai berikut :

$$
\begin{aligned}
& \text { RHR }=140 \\
& \text { MHR }=220-\text { usia } \\
& =220-31 \\
& =189 \\
& \mathrm{HRR}=\mathrm{MHR}-\mathrm{RHR} \\
& =189-140 \\
& =49 \\
& =0,5 \times 189 \\
& =94,5 \\
& =0,69 \times 189 \\
& =130,4
\end{aligned}
$$

Rekomendasi aktivitas yang diberikan oleh sistem untuk mencapai target denyut jantung yang dituju adalah "Turunkan aktivitas" dengan diberikan beberapa alternatif pilihan aktivitas yang dapat dilakukan oleh tester. Hal ini dikarenakan hasil tapping data RHR berada diatas nilai 
minimal THR yang harus dicapai.

Profil tester kedua dilakukan uji coba ulang dengan cara merubah status level tingkat aktivitas tester dari yang awalnya "Sedang" menjadi "Berat" didapatkan hasil sebagai berikut :

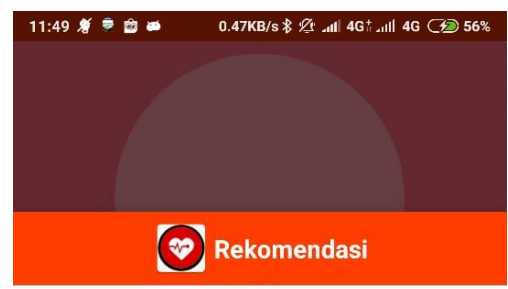

Gambar 8. Hasil pengukuran dan analisa denyut jantung tester kedua pada level aktivitas "Berat"

Berdasarkan data profil tester kedua diatas, karena hasil pengukuran denyut jantung tester pada saat pengujian adalah 140 maka status kondisi jantung termasuk dalam kategori "Tachycardia". Rekomendasi aktivitas disesuaikan dengan status aktivitas tester yaitu "Berat" dengan diberikan informasi tentang standar nilai minimum dan maksimum target denyut jantung yang harus dicapai. Target denyut jantung yang harus dicapai berada di kisaran 132,3 hingga 160,7. Target denyut jantung ini didapat dari hasil perhitungan sebagai berikut :

$$
\begin{aligned}
\text { RHR } & =140 \\
\text { MHR } & =220-\text { usia } \\
& =220-31 \\
& =189 \\
\text { HRR } & =\text { MHR }- \text { RHR } \\
& =189-140 \\
& =49
\end{aligned}
$$

Min. THR $=0,7 \times$ MHR

$$
=0,7 \times 189
$$

$$
=132,3
$$

Max. THR $=0,85 \times$ MHR

$$
=0,85 \times 189
$$$$
=160,7
$$

Rekomendasi aktivitas yang diberikan oleh sistem untuk mencapai target denyut jantung yang dituju adalah tetap "Turunkan aktivitas" dengan diberikan beberapa alternatif pilihan aktivitas yang dapat dilakukan oleh tester. Sebab meski level aktivitas tester sudah diubah menjadi "Berat", hasil tapping data RHR masih diatas nilai minimal THR yang harus dicapai. Sehingga rekomendasi aktivitas adalah tetap "Turunkan aktivitas".

3. Data profil tester ketiga adalah sebagai berikut:

Padmi Wahyu, seorang wanita berusia 31 tahun dengan berat badan $79 \mathrm{~kg}$ yang memiliki level tingkat aktivitas berat.

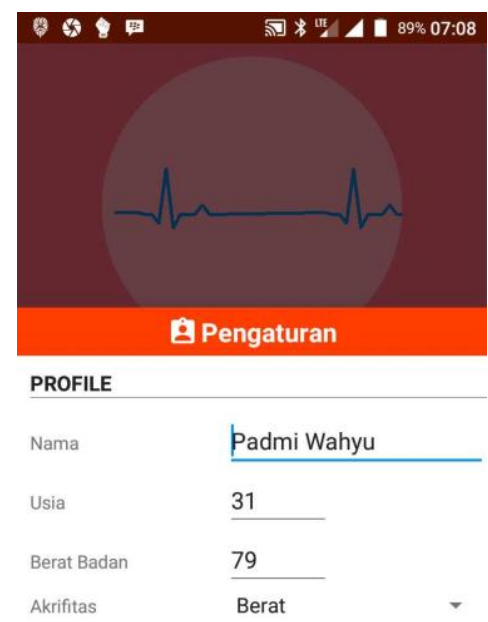

Gambar 9. Data profil tester ketiga

Hasil pengukuran denyut jantung dari tester Padmi Wahyu menunjukkan informasi sebagai berikut :
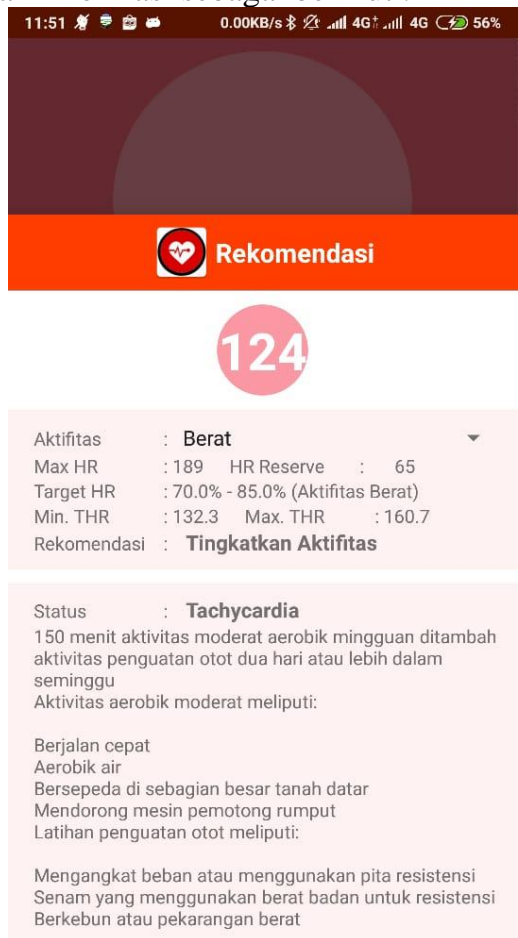

Gambar 10. Hasil pengukuran dan analisa denyut jantung tester ketiga pada level aktivitas "Berat" 
Berdasarkan profil tester diatas, karena hasil pengukuran denyut jantung tester adalah 124 maka status kondisi jantung ada kecenderungan untuk mengalami "Tachycardia". Rekomendasi aktivitas disesuaikan dengan status aktivitas tester yaitu "Berat" dengan diberikan informasi tentang standar nilai minimum dan maksimum target denyut jantung yang harus dicapai agar kondisi jantung menjadi "Normal". Target denyut jantung yang harus dicapai berada di kisaran 132,3 hingga 160,7. Target denyut jantung ini didapat dari hasil perhitungan sebagai berikut:

$$
\begin{aligned}
& \text { RHR }=124 \\
& \text { MHR }=220-\text { usia } \\
& =220-31 \\
& =189 \\
& \mathrm{HRR}=\mathrm{MHR}-\mathrm{RHR} \\
& =189-124 \\
& =65 \\
& =0,7 \times 189 \\
& =132,3 \\
& =0,85 \times 189 \\
& =160,65
\end{aligned}
$$

Rekomendasi aktivitas yang diberikan oleh sistem untuk mencapai target denyut jantung yang dituju adalah "Tingkatkan aktivitas" dengan diberikan beberapa alternatif pilihan aktivitas yang dapat dilakukan oleh tester. Hal ini dikarenakan hasil tapping data RHR berada dibawah nilai minimal THR yang harus dicapai.

Profil tester ketiga dilakukan uji coba ulang dengan cara merubah status level tingkat aktivitas tester dari yang awalnya "Berat" menjadi "Sedang" didapatkan hasil sebagai berikut :

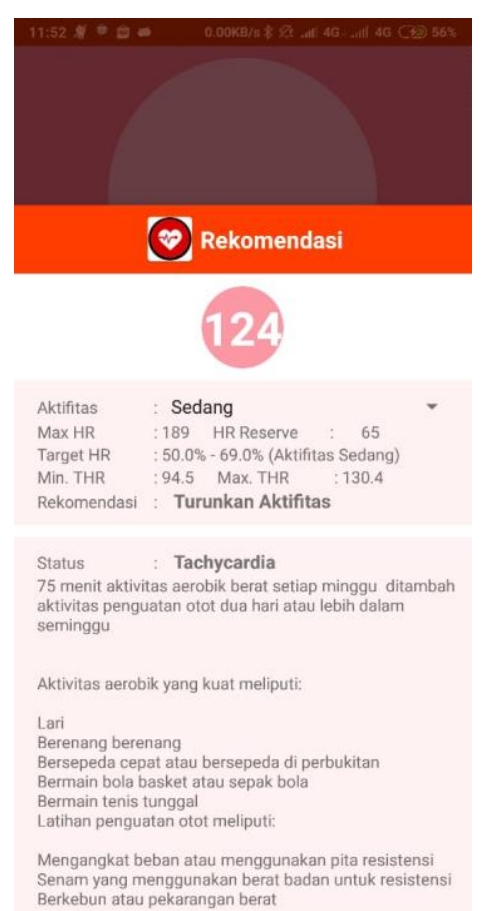

Gambar 11. Hasil pengukuran dan analisa denyut jantung tester ketiga pada level aktivitas "Sedang"
Berdasarkan data profil tester ketiga diatas, karena hasil pengukuran denyut jantung tester pada saat pengujian adalah 124 maka status kondisi jantung termasuk dalam kategori "Tachycardia". Rekomendasi aktivitas disesuaikan dengan status aktivitas tester yaitu "Sedang" dengan diberikan informasi tentang standar nilai minimum dan maksimum target denyut jantung yang harus dicapai. Target denyut jantung yang harus dicapai berada di kisaran 94,5 hingga 130,4. Target denyut jantung ini didapat dari hasil perhitungan sebagai berikut :

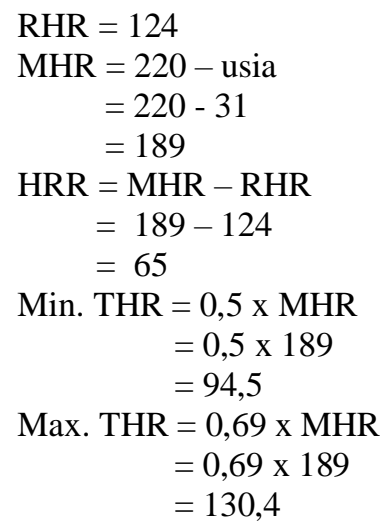

Rekomendasi aktivitas yang diberikan oleh sistem untuk mencapai target denyut jantung yang dituju adalah berubah menjadi "Turunkan aktivitas" dengan diberikan beberapa alternatif pilihan aktivitas yang dapat dilakukan oleh tester. Karena level aktivitas tester sudah diubah menjadi "Sedang" dan hasil tapping data RHR menunjukkan nilai RHR berada diatas nilai minimal THR yang harus dicapai sehingga rekomendasi aktivitas berubah menjadi "Turunkan aktivitas".

Hasil percobaan penggunaan aplikasi SIBioS pada 3 tester diatas dengan ragam kondisi tester yang berbeda-beda menunjukkan bahwa aplikasi SIBioS mampu menentukan status kondisi jantung dari masing-masing tester dengan benar. Sistem juga mampu menyesuaikan rekomendasi aktivitas yang diberikan sesuai dengan profil tester yang diuji.

\section{KESIMPULAN}

Dari pengujian aplikasi SIBioS terhadap 3 contoh kasus yang berbeda, SIBioS mampu memberikan informasi tentang status kondisi jantung tester sesuai dengan kondisi riil tester pada saat dilakukan pengukuran. Metode analisa case based reasoning dapat diterapkan pada analisa denyut jantung untuk menentukan kondisi jantung seseorang dalam kondisi normal atau adanya gangguan kardiovaskuler. Rekomendasi aktifitas fisik yang diberikan oleh sistem ditentukan berdasarkan kondisi jantung individu tersebut. Jika nilai Resting Heart Rate (RHR) berada di kisaran 60100 (dalam kondisi tertentu) maka dikatakan normal. Jika kurang dari 60 dicurigai ada indikasi gangguan kardiovaskuler bradycardia. Sebaliknya jika diatas 100 terindikasi gangguan kardiovaskuler tachycardia. Analisa terhadap nilai Target Heart Rate (THR) yang didapat menjadi acuan rekomendasi aktivitas fisik bagi pengguna. Hasil pengukuran juga dipengaruhi oleh piranti smartwatch yang digunakan sebagai media tapping data denyut jantung. Faktor-faktor yang berpengaruh terhadap analisa denyut 
jantung diantaranya adalah jenis kelamin, usia, aktivitas fisik harian, status profesi individu dan faktor pendukung pada saat dilakukan pengukuran resting heart rate.

\section{REFERENSI}

[1] Media Centre, 2017, Fact Sheet of Cardiovascular Diseases (CVDs) Updated : May 2017, World Health Organization (WHO).

[2] Tias, Rahmawati F, Mahaputra Hidayat, "Analisis dan Desain SiBIOS Deteksi Dini Kondisi Jantung dan Peningkatan Kualitas Hidup Manusia", Jurnal Techno.COM LPPM Universitas Dian Nuswantoro Semarang, Vol. 17 No. 3 edisi Agustus 2018, hal. 333-342

[3] Schmidt, Rainer, Stefania Montani, Riccardo Bellazi, Luigi Portinale, Lothar Gierl, "Cased-Based Reasoning for Medical Knowledge-Based Systems", International Journal of Medical Informatics, Vol. 64 No. 2-3 edisi Desember 2001, DOI : https://doi.org/10.1016/S1386-5056(01)00221-0

[4] Kolodner, Janet, Case-Based Reasoning, Morgan Kaufmann Publisher Inc, 2014.

[5] Utomo, Dito Putro, Surya Darma Nasution, "Sistem Pakar Mendeteksi Kerusakan Toner Dengan Menggunakan Metode CaseBased Reasoning", Jurnal Riset Komputer (JURIKOM) STMIK Budi Darma Medan, Vol. 3 No. 5 edisi Oktober 2016, hal. 430-434

[6] Mulyana, Sri, Sri Hartati, "Tinjauan Singkat Perkembangan CaseBased Reasoning", Prosiding Seminar Nasional Informatika (semnasIF) UPN Veteran Jogjakarta 2009, tanggal 23 Mei 2009, hal. D-17 - D-18.

[7] Pahlawan, Arno Reza, Setyawan Wibisono, "Implementasi Case Based Reasoning Untuk Sistem Diagnosis Hama Dan Penyakit Tanaman Cabe Merah Menggunakan Algoritma Similaritas Neyman”, Prosiding SINTAK 2017 Universitas Stikubank (UNIBANK) Semarang, hal. 155-162.

[8] Purwandani, Indah, "Penerapan Case Based Reasoning dan Nearest Neighbor Retrieval Untuk Diagnosa Penyakit Langganan Anak", Jurnal Sentra Penelitian Engineering dan Edukasi (Speed) Asosiasi Profesi Multimedia Indonesia Boyolali, Vol. 9 No. 2 edisi Juni 2017, hal. 20-26.

[9] Wahyudi, Eka, Sri Hartati, "Case Based Reasoning Untuk Diagnosis Penyakit Jantung", Indonesian Journal of Computing and Cybernetics Systems (IJCCS) FMIPA Universitas Gajah Mada Jogjakarta, Vo. 11 No. 1 edisi Januari 2017, hal. 1-10.

[10] Halim, Arwin, Hernawati Gohzali, In Sin, Kelvin Wijaya, "Aplikasi Content Based Image Retrieval Dengan Algoritma Sobel's Edge Detection", Prosiding Seminar Nasional Informatika (SNIf) 2015 Universitas Potensi Utama Medan, Vo. 1 No. 1 Agustus 2015, hal. 3137.

[11] Asroni, Hidayatul Fitri, Eko Prasetyo, "Penerapan Metode Clustering dengan Algoritma K-Means pada Pengelompokkan Data Calon Mahasiswa Baru di Universitas Muhammadiyah Yogyakarta (Studi Kasus: Fakultas Kedokteran dan Ilmu Kesehatan, dan Fakultas Ilmu Sosial dan Ilmu Politik)", Jurnal Semesta Teknika Fakultas Teknik Universitas Muhammadiyah Yogyakarta Vo. 21 No. 1 edisi Mei 2018, hal. 61-64. 